\title{
Comparative Sequence Analyses of the Genes Coding for 16S rRNA of Lactobacillus casei-Related Taxa
}

\author{
KATSUMI MORI, ${ }^{1 *}$ KOJI YAMAZAKI, ${ }^{2}$ TOMOHARU ISHIYAMA,${ }^{1} \dagger$ MASAHIRO KATSUMATA, ${ }^{1} \ddagger$ \\ KAYO KOBAYASHI, ${ }^{1} \S$ YUJI KAWAI, ${ }^{2}$ NORIO INOUE, ${ }^{2}$ AND HARUO SHINANO ${ }^{2}$ \\ Systematic Microbiology Laboratory, National Food Research Institute, Ministry of Agriculture, Forestry and Fisheries, \\ 2-1-2 Kannondai, Tsukuba, Ibaraki 305, ${ }^{1}$ and Faculty of Fisheries, Hokkaido University, \\ Hakodate, Hokkaido $041,{ }^{2}$ Japan
}

\begin{abstract}
The primary structures of the 16S rRNA genes of the type strains of Lactobacillus casei and related taxa were determined by PCR DNA-sequencing methods. The sequences of Lactobacillus casei, Lactobacillus zeae, Lactobacillus paracasei, and Lactobacillus rhamnosus were different. The $K_{\text {nuc }}$ values ranged from 0.0040 to 0.0126 . On the basis of the $K_{\text {nuc }}$ values and the levels of DNA-DNA relatedness among the strains of these species, the $L$. case $i$-related taxa should be classified in the following three species: $L$. zeae, which includes the type strains of $L$. zeae and $L$. casei; a species that includes the strains of $L$. paracasei and $L$. casei ATCC 334; and $L$. rhamnosus.
\end{abstract}

Members of Lactobacillus casei are gram-positive, facultatively anaerobic, catalase-negative, facultatively heterofermentative, non-spore-forming rods and are isolated from many habitats (e.g., meats, milk, dairy products, sour dough, silage, and sewage). Five subspecies of this species, L. casei subsp. casei (Orla-Jensen 1916) Hansen and Lessel 1971, L. casei subsp. alactosus Mills and Lessel 1973, L. casei subsp. pseudoplantarum Abo-Elnaga and Kandler 1965, L. casei subsp. rhamnosus Hansen 1968, and L. casei subsp. tolerans Abo-Elnaga and Kandler 1965, were recognized on the Approved Lists of Bacterial Names on the basis of phenotypic criteria (16). Then, in Bergey's Manual of Systematic Bacteriology (11), the five subspecies of $L$. casei were reclassified into four subspecies $(L$. case $i$ subsp. alactosus was combined with $L$. case $i$ subsp. casei) on the basis of the comprehensive studies of Dellaglio et al. (7). In 1989, Collins et al. (3) reclassified the subspecies of $L$. casei into the following three species on the basis of DNADNA relatedness data: $L$. casei, Lactobacillus paracasei, and Lactobacillus rhamnosus. In 1991, Dellaglio et al. requested a change in the designation of the neotype strain of $L$. case $i$ subsp. case $i$ and rejection of the name L. paracase $i$ as a synonym of $L$. casei (8). However, the Judicial Commission of the International Committee on Systematic Bacteriology voted against this request (20). In 1996, Dicks et al. proposed that the species name Lactobacillus zeae should be revised and that strain ATCC 334 should be designated the neotype strain of $L$. case $i$ subsp. case $i$ and thus the name $L$. paracase $i$ should be rejected (9).

The study of $16 \mathrm{~S}$ rRNA sequences is now considered to be a powerful technique for determining the phylogenetic relationships of microorganisms $(1,4-6,13,19,22,23)$. Weisburg et al. determined the $16 \mathrm{~S}$ rRNA sequence of the type strain of L. casei (accession number M23928), Woese et al. determined the $16 \mathrm{~S}$ rRNA sequence of the type strain of $L$. rhamnosus (accession number M58815), and Hammes et al. described the phylogenetic relationship between $L$. casei and L. rhamnosus

\footnotetext{
* Corresponding author.

$\uparrow$ Present address: Ishiyama Miso-Shoyu Co., Ltd., Niigata-shi, Japan.

$\ddagger$ Present address: Hagoromo Foods Co., Ltd., Shimizu-shi, Japan.

$\S$ Present address: Du Pont K.K., Meguro-ku, Tokyo, Japan.
}

(10). Collins also determined the 16S rRNA sequences of the type strains of $L$. casei, $L$. paracasei, and $L$. rhamnosus (6).

However, the 16S rRNA sequences of all of the type strains of the $L$. casei subspecies and the phylogenetic relationships among these strains have not been analyzed, so the classification of the $L$. casei group is not yet stable. Therefore, we analyzed ca. 1,520 nucleotides of the genes coding for the $16 \mathrm{~S}$ rRNA (16S rDNA) in all of the type strains of the $L$. case $i$ subspecies and closely related strains and then determined the phylogenetic relationships of these organisms.

\section{MATERIALS AND METHODS}

Bacterial strains and cultivation. The strains used in this study are shown in Table 1. These strains were grown aerobically on Briggs agar (Nissui Seiyaku, Inc., Tokyo, Japan) slants for 2 to 3 days at $30^{\circ} \mathrm{C}$

Extraction and determination of the 16S rDNA sequence. Total DNA was extracted and purified from a loopful of cells of each strain with an InstaGene purification matrix (Bio-Rad Laboratories, Richmond, Calif.) according to the protocol for bacteria (2). The 16S rDNA fragments in the total DNA were amplified by the modified PCR methods of Wittwer and Garling (21) by using a model 1605 air thermocycler (Idaho Technology, Inc.) and 50- $\mu$ l glass capillary tubes. Eleven fragments of the $16 \mathrm{~S}$ rDNA were amplified to facilitate amplification and sequencing. The 11 pairs of primers used for amplification are shown in Table 2 . The sequence of primer $-21 \mathrm{M} 13$ was connected to the $5^{\prime}$ end region of one primer from each pair, and so a strand of the PCR product contained a complementary sequence of $-21 \mathrm{M} 13$ in the $3^{\prime}$ end region to which the $-21 \mathrm{M} 13$ universal fluorescent primer annealed for sequencing. The nucleotide sequences of the strands which contained the complementary sequence of $-21 \mathrm{M} 13$ were determined with a model 373A DNA sequencer (Applied Biosystems, Inc., Foster City, Calif.) by the dideoxynucleotide chain termination method modified for use with the $-21 \mathrm{M} 13$ universal fluorescent primer and a Taq dye primer cycle sequencing kit (Applied Biosystems, Inc.) (14).

Data analysis. The sequences that were generated were aligned by using the program DNASIS (Hitachi Software Engineering Co., Ltd., Tokyo, Japan). Homology values and evolutionary distances $\left(K_{\text {nuc }}\right.$ values $)(12,18)$ were calculated and an unrooted phylogenetic tree was produced by the neighbor-joining method (15), using Saitou's NJ computer program.

Nucleotide sequence accession numbers. The nucleotide sequences of the $16 \mathrm{~S}$ rDNAs determined in this study have been deposited in the GSDB, DDBJ, EMBL, and NCBI nucleotide sequence databases under the accession numbers shown in Table 1.

\section{RESULTS AND DISCUSSION}

Sequences of the $16 \mathrm{~S}$ rDNAs of $L$. case $i$-related strains. The sequences of more than 1,520 nucleotides of the $16 \mathrm{~S}$ rDNAs (homologous to positions 28 to 1,521 of the Escherichia coli 16S rRNA sequence) were determined for all of the strains tested by the PCR DNA-sequencing method. Weisburg et al. 
TABLE 1. Strains tested, accession numbers of $16 \mathrm{~S}$ rDNAs, and DNA-DNA relatedness among the strains

\begin{tabular}{|c|c|c|c|c|c|}
\hline \multirow{2}{*}{ Strain } & \multicolumn{4}{|c|}{ \% DNA relatedness with DNA from: } & \multirow{2}{*}{ Basonym (accession no. of $16 \mathrm{~S}$ rDNA) } \\
\hline & $\overline{\text { ATCC } 393^{\mathrm{Ta}}}$ & NCDO $161^{\mathrm{T} b}$ & $\operatorname{ATCC} 334^{a}$ & $\mathrm{NCDO} 151^{\mathrm{T} b}$ & \\
\hline $\begin{array}{l}\text { L. zeae ATCC } 15820^{\mathrm{T}}\left(=\text { DSM } 20178^{\mathrm{T}}\right. \\
\left.=\text { NCIB } 9537^{\mathrm{T}}\right)\end{array}$ & 80 & & 42 & & L. rhamnosus ATCC 15820 (D86516) \\
\hline $\begin{array}{l}\text { L. casei JCM } 1134^{\mathrm{T}}\left(=\operatorname{ATCC} 393^{\mathrm{T}}\right. \\
\left.=\text { NCDO } 161^{\mathrm{T}}\right)\end{array}$ & 100 & 100 & 36 & 16 & L. casei subsp. casei JCM $1134^{\mathrm{T}}$ (D16551) \\
\hline L. casei JCM 8129 (= NCDO 173) & & 80 & & & L. casei subsp. casei JCM 8129 (D86518) \\
\hline L. casei ATCC 334 & 43 & & 100 & & L. casei subsp. casei ATCC 334 (D86517) \\
\hline $\begin{array}{l}\text { L. paracasei subsp. paracasei } \mathrm{JCM} 8130^{\mathrm{T}} \\
\left(=\mathrm{NCDO} 151^{\mathrm{T}}\right)\end{array}$ & 22 & 15 & 95 & 100 & L. casei subsp. casei JCM 8130 (D79212) \\
\hline $\begin{array}{l}\text { L. paracasei subsp. paracasei JCM } 1133 \\
(=\text { ATCC } 27216=\text { NCDO } 2713)\end{array}$ & 50 & 26 & 85 & 85 & $\begin{array}{l}\text { L. casei subsp. alactosus JCM } 1133^{\mathrm{T}} \\
\text { (D16548) }\end{array}$ \\
\hline $\begin{array}{l}\text { L. paracasei subsp. paracasei JCM } 1181 \\
(=\text { NCDO } 2743=\text { DSM } 20008)\end{array}$ & 33 & 13 & 86 & 65 & $\begin{array}{l}\text { L. casei subsp. pseudoplantanum JCM } 1181^{\mathrm{T}} \\
\text { (D16549) }\end{array}$ \\
\hline $\begin{array}{l}\text { L. paracasei subsp. tolerans JCM } 1171^{\mathrm{T}} \\
\left(=\text { ATCC } 25599^{\mathrm{T}}=\text { DSM } 20258^{\mathrm{T}}\right)\end{array}$ & & 15 & & 86 & $\begin{array}{l}\text { L. casei subsp. tolerans JCM } 1171^{\mathrm{T}} \\
\text { (D16550) }\end{array}$ \\
\hline $\begin{array}{l}\text { L. rhammosus JCM } 1136^{\mathrm{T}}(=\text { ATCC } \\
\left.7469^{\mathrm{T}}=\text { NCDO } 243^{\mathrm{T}}\right)\end{array}$ & 45 & 15 & 47 & 9 & $\begin{array}{l}\text { L. casei subsp. rhamnosus JCM } 1136^{\mathrm{T}} \\
\text { (D16552) }\end{array}$ \\
\hline
\end{tabular}

${ }^{a}$ Data from references 8 and 9 .

${ }^{b}$ Data from reference 3 .

reported the 16S rRNA sequence of type strain ATCC 393 of L. casei (accession number M23928). In the present study, the sequence of type strain JCM 1134 of $L$. casei (accession number D16551) included 23 bases that Weisburg et al. reported as unknown. One base determined in this study did not agree with the data of Weisburg et al. The nucleotide at position 534 (E. coli numbering) was determined to be $\mathrm{T}$ in our study and $\mathrm{C}$ in the study of Weisburg et al. Woese et al. determined the $16 \mathrm{~S}$ rRNA sequence of type strain DSM 20021 of $L$. rhamnosus (accession number M58815). Our sequence data for type strain

TABLE 2. Sequences of oligonucleotides used as primers for 16S rDNA amplification

\begin{tabular}{|c|c|c|}
\hline Pair no. & Primer & Sequence $\left(5^{\prime}-3^{\prime}\right)^{a}$ \\
\hline & $-21 \mathrm{M} 13$ & TGTAAAACGACGGCCAGT \\
\hline 11 & $\begin{array}{l}\mathrm{M} 27 \mathrm{~F} \\
520 \mathrm{R}\end{array}$ & $\begin{array}{c}\text { (-21M13)-AGAGTTTGATCCTGGCTCAG } \\
\text { ACCGCGGC(G/T)GCTGGC }\end{array}$ \\
\hline 12 & $\begin{array}{l}\text { M357F } \\
777 \mathrm{R}\end{array}$ & $\begin{array}{l}\text { (-21M13)-CTACGGGAGGCAGCAG } \\
\text { GTATCTAATCCTGTT(T/C)GCT }\end{array}$ \\
\hline 13 & $\begin{array}{l}\mathrm{M} 703 \mathrm{~F} \\
1080 \mathrm{R}\end{array}$ & $\begin{array}{c}\text { (-21M13)-GCGGTGAAATGCGTAG } \\
\text { CCCAACATCTCACGAC }\end{array}$ \\
\hline 14 & $\begin{array}{l}\text { M920F } \\
1400 \mathrm{R}\end{array}$ & $\begin{array}{c}\text { (-21M13)-AAACTCAAAGGAATTGACGG } \\
\text { ACGGGCGGTGTGT(G/A)C }\end{array}$ \\
\hline 15 & $\begin{array}{l}\text { M1240F } \\
1522 \mathrm{R}\end{array}$ & $\begin{array}{l}(-21 \mathrm{M} 13)-A C A C A C G T G C T A C A A T \\
\text { AAGGAGGTGATCCA(A/G)CCGCA }\end{array}$ \\
\hline 161 & $\begin{array}{l}\text { M246R } \\
\text { N27F }\end{array}$ & $\begin{array}{c}(-21 \mathrm{M} 13)-\mathrm{TTACC}(\mathrm{T} / \mathrm{C}) \mathrm{CACC}(\mathrm{A} / \mathrm{T}) \mathrm{ACTAGCT} \\
\text { AGAGTTTGATCCTGGCTCAG }\end{array}$ \\
\hline 162 & $\begin{array}{l}\text { M400R } \\
\mathrm{N} 27 \mathrm{~F}\end{array}$ & $\begin{array}{c}\text { (-21M13)-AAAICCTTC(T/A)TCAC(T/A)CAC } \\
\text { AGAGTTTGATCCTGGCTCAG }\end{array}$ \\
\hline 171 & $\begin{array}{l}\text { M700R } \\
359 \mathrm{~F}\end{array}$ & $\begin{array}{c}\text { (-21M13)-AT(A/C)TCTACGCATT(T/C)CACCGC } \\
\text { CTACGGGAGGCAGCAGTAG }\end{array}$ \\
\hline 18 & $\begin{array}{l}\text { M920R } \\
530 F\end{array}$ & $\begin{array}{c}\text { (-21M13)-CCGTCAATTC(C/A)TTT(G/A)AGTTT } \\
\text { GTGCCAGCCGCCGCGG }\end{array}$ \\
\hline 19 & $\begin{array}{l}\text { M1240R } \\
790 \mathrm{~F}\end{array}$ & $\begin{array}{r}\text { (-21M13)-CCATTGTAGCACGTGTGTAG } \\
\text { AGC(A/G)AACAGGATTAGATAC }\end{array}$ \\
\hline 20 & $\begin{array}{l}\text { M1522R } \\
1080 F\end{array}$ & $\begin{array}{r}\text { (-21M13)-AAGGAGGTGATCCA(A/G)CCGCA } \\
\text { GT(C/T)GTGA(G/A)ATGTTGGGTTAAG }\end{array}$ \\
\hline
\end{tabular}

\footnotetext{
${ }^{a}(-21 \mathrm{M} 13)$, sequence of $-21 \mathrm{M} 13$.
} 

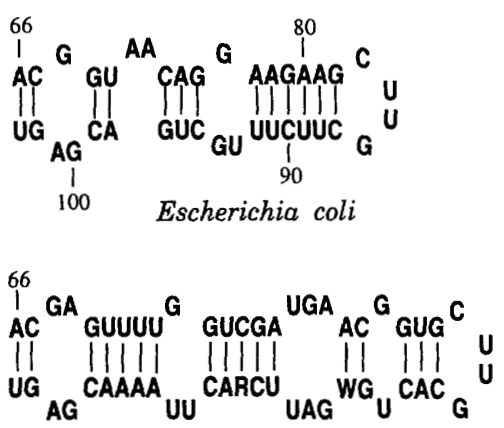

L. casei JCM 1134T

L. casei JCM 8129

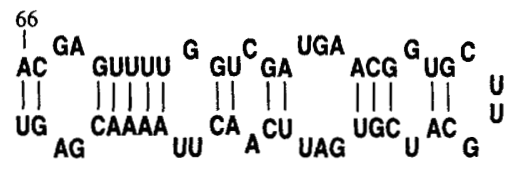

L. zeae ATCC $15820^{\mathrm{T}}$

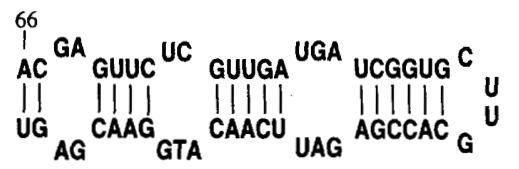

L. paracasei subsp. paracasei JCM 8130T, JCM 1133, JCM 1181 L. paracasei subsp. tolerans JCM 1171T

L. casei ATCC 334

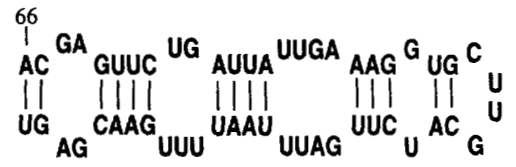

L. rhamnosus JCM $1136^{\mathrm{T}}$

FIG. 1. Secondary structures of 16S rRNAs of the type strains of $L$. case $i$ and related taxa at $E$. coli $16 \mathrm{~S}$ rRNA positions 66 to 103 . R, A or G; W, A or T.

JCM 1136 of L. rhamnosus (accession number D16552) included 47 bases that Woese et al. reported as unknown. Also, only one base in our sequence did not agree with the data of Woese et al.; the nucleotide at position 1028 (E. coli numbering) in our sequence was $\mathrm{C}$, and there was a gap at this position in the sequence of Woese et al. Collins et al. reported that they determined ca. 1,490 bases of the 16S rRNA sequences of L. casei NCDO $161^{\mathrm{T}}$ ( $\mathrm{T}=$ type strain $), L$. paracasei $\mathrm{NCDO}$ $151^{\mathrm{T}}$, and L. rhamnosus NCDO $243^{\mathrm{T}}$ and that more than $99 \%$ sequence homology was exhibited by these three species (6). The data for $L$. casei only (accession number X61135) appeared in the nucleotide sequence databases. Although we also used type strain JCM 1134 of $L$. casei, our sequence data

TABLE 3. $K_{\text {nuc }}$ values for $16 \mathrm{~S}$ rDNAs of $L$. casei-related species

\begin{tabular}{llcc}
\hline \multirow{2}{*}{ Species } & \multicolumn{3}{c}{$K_{\text {nuc value with: }}$} \\
\cline { 2 - 4 } & L. casei & L. zeae & L. paracase \\
\hline L. zeae & 0.0040 & & \\
L. paracasei & 0.0073 & 0.0086 & \\
L. rhamnosus & 0.0086 & 0.0126 & 0.0113 \\
\hline
\end{tabular}

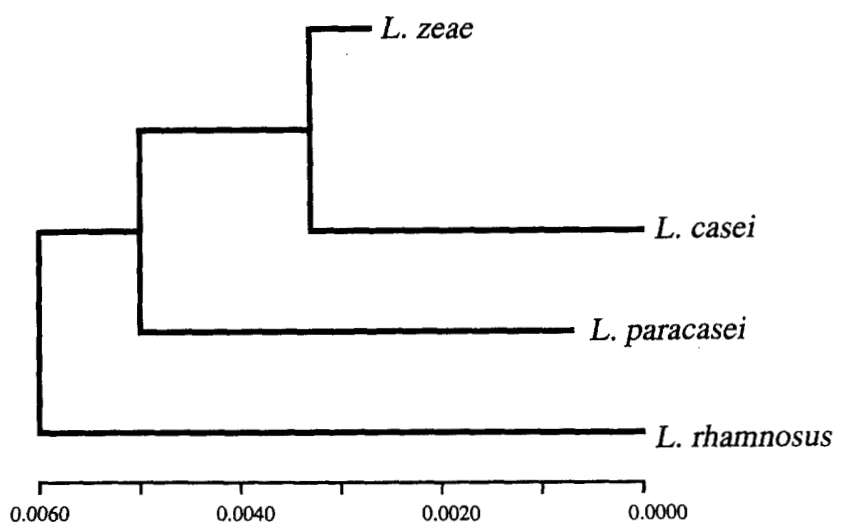

Knuc value

FIG. 2. Unrooted tree showing the phylogenetic relationships of $L$. casei and related taxa. The evolutionary distance between any two taxa is the sum of the lengths of the horizontal lines between them.

(accession number D16551) did not agree with the data of Collins et al. (accession number X61135) at 31 positions. At these 31 positions, our data agreed completely with the data of Weisburg et al. (accession number M23928). Our data included 125 bases that Collins et al. reported as unknown.

In a comparison of the sequences of all of the strains tested, we found that the sequences of the strains belonging to the species $L$. paracasei (that is, L. paracasei subsp. paracasei JCM $8130^{\mathrm{T}}$ [basonym, L. casei subsp. casei JCM 8130], L. paracasei subsp. paracasei JCM 1133 [basonym, L. casei subsp. alactosus JCM $1133^{\mathrm{T}}$ ], L. paracasei subsp. paracasei JCM 1181 [basonym, $L$. casei subsp. pseudoplantarum JCM $\left.1181^{\mathrm{T}}\right]$, and $L$. paracasei subsp. tolerans JCM $1171^{\mathrm{T}}$ [basonym, L. casei subsp. tolerans JCM $1171^{\mathrm{T}}$ ]) and the sequence of $L$. casei ATCC 334 were the same. The sequences of the $L$. casei strains ( $L$. casei JCM $1134^{\mathrm{T}}$ and L. casei JCM 8129) were also the same. However, the sequences of the type strains of the four species studied (L. casei JCM 1134, L. zeae ATCC 15820, L. paracasei JCM 8130, and L. rhamnosus JCM 1136) were different. The number of base differences between $L$. case $i$ and $L$. zeae was 6 , and the numbers of base differences among the other species were 11 to 19 .

Comparative analysis of the potential secondary structures of the 16S rRNAs estimated from the 16S rDNA sequences of the $L$. case $i$-related strains revealed a region in which there are differences. This is the region from position 69 to position 100 ( $E$. coli numbering); the potential secondary structures are shown in Fig. 1. At present it is still not known whether the function of 16S rRNA is influenced by such differences in the secondary structure.

TABLE 4. Sequence signatures in the 16S rDNAs of $L$. caseirelated taxa

\begin{tabular}{|c|c|c|c|c|c|c|c|c|c|c|c|c|c|}
\hline \multirow{2}{*}{ Species } & \multicolumn{13}{|c|}{ Nucleotide at position ${ }^{a}$ : } \\
\hline & 73 & 75 & 76 & 84 & 85 & 96 & 97 & 98 & 104 & 107 & 108 & 110 & 111 \\
\hline L. casei & $\mathrm{T}$ & $\mathrm{G}$ & $G$ & A & $\mathrm{C}$ & $\mathrm{C}$ & $\mathbf{T}$ & $\mathrm{G}$ & $\mathrm{C}$ & $\mathrm{C}$ & $\mathrm{T}$ & A & A \\
\hline L. zeae & $\mathrm{T}$ & $\mathrm{G}$ & $\mathrm{G}$ & A & $\mathrm{C}$ & $\mathrm{T}$ & $\mathrm{C}$ & $\mathrm{G}$ & $\mathrm{C}$ & $\mathrm{C}$ & $\mathrm{T}$ & A & A \\
\hline L. paracasei & $\mathrm{C}$ & $\mathrm{C}$ & $\mathrm{G}$ & $\mathrm{T}$ & $\mathrm{C}$ & $\mathrm{C}$ & $\mathrm{C}$ & $\mathrm{G}$ & $\mathrm{C}$ & $\mathrm{C}$ & A & $\mathrm{G}$ & $\mathrm{G}$ \\
\hline L. rhamnosus & $\mathrm{C}$ & $\mathrm{G}$ & A & A & A & $\mathrm{T}$ & $\mathrm{C}$ & $\mathrm{T}$ & $\mathrm{T}$ & $\mathbf{T}$ & $\mathrm{T}$ & $\mathrm{T}$ & G \\
\hline
\end{tabular}

${ }^{a}$ Position from the $S^{\prime}$ end of the $16 \mathrm{~S}$ rRNA sequence of $L$. casei. 
Phylogenetic relationships among $L$. casei, L. zeae, L. paracase $i$, and $L$. rhamnosus. Evolutionary distances ( $K_{\text {nuc }}$ values) among the strains tested were calculated (Table 3), and a phylogenetic tree based on these $K_{\text {nuc }}$ values is shown in Fig. 2. The evolutionary distance between $L$. case $i$ and $L$. rhamnosus agreed with the distance reported by Hammes et al. (10).

For species definitions, sequence analysis of $16 \mathrm{~S}$ rRNA is the level at which DNA pairing studies need to be performed (17). The $K_{\text {nuc }}$ value between $L$. casei JCM $1134^{\mathrm{T}}$ (or $L$. casei JCM 8129 ) and $L$. zeae ATCC $15820^{T}$ was 0.0040 , about one-half of the values determined for the other species. Because of this low $K_{\text {nuc }}$ value and the high DNA-DNA relatedness (Table 1) between these strains reported by Dellaglio et al. (8), it was thought that these organisms should be classified in the species $L$. zeae. The sequences of the strains of $L$. paracase $i$ and $L$. casei ATCC 334 (which Dicks et al. has proposed to designate the neotype strain of $L$. casei subsp. casei) were the same, and Dellaglio et al. also reported high DNA-DNA relatedness (Table 1 ) between $L$. paracasei NCDO $151^{\mathrm{T}}$ and $L$. casei ATCC 334 (8). Therefore, the strains of $L$. paracase $i$ and $L$. casei ATCC 334 should be classified in one species. The sequence of L. rhamnosus JCM $1136^{\mathrm{T}}$ was clearly distinct from the sequences of the other species tested and was consistent with the classification of $L$. rhamnosus proposed by Collins et al. (3).

Sequence signature. The sequence alignments demonstrated that $L$. casei, $L$. zeae, $L$. paracasei, and $L$. rhamnosus could be readily distinguished from each other. The sequence signatures which distinguish these four species from each other are shown in Table 4.

\section{ACKNOWLEDGMENTS}

We are grateful to $\mathrm{H}$. Oyaizu, The University of Tokyo, for technical advice and for supplying primers 520R, 1080R, and 1400R.

This study was supported in part by a grant-in-aid (Silage Program) from the Ministry of Agriculture, Forestry and Fisheries, Japan.

\section{REFERENCES}

1. Bentley, R. W., J. A. Leigh, and M. D. Collins. 1991. Intragenetic structure of Streptococcus based on comparative analysis of small-subunit rRNA sequences. Int. J. Syst. Bacteriol. 41:487-494.

2. Bio-Rad Laboratories. 1992. InstaGene purification matrix manual. Bio-Rad Laboratories, Richmond, Calif,

3. Collins, M. D., B. A. Phillips, and P. Zanoni. 1989. Deoxyribonucleic acid homology studies of Lactobacillus casei, Lactobacillus paracasei sp. nov., subsp. paracasei and subsp. tolerans, and Lactobacillus rhamnosus sp. nov., comb. nov. Int J. Syst. Bacteriol 39:105-108.

4. Collins, M. D., C. Ash, J. A. E. Farrow, S. Wallbanks, and A. M. Williams. 1989. 16S ribosomal ribonucleic acid sequence analyses of lactococci and related taxa, description of Vagococcus fluvialis gen. nov., sp. nov. J. Appl. Bacteriol. 67:453-460.
5. Collins, M. D., A. M. Williams, and S. Wallbanks. 1990. The phylogeny of Aerococcus and Pediococcus as determined by $16 \mathrm{~S}$ rRNA sequence analysis: description of Tetragenococcus gen. nov. FEMS Microbiol. Lett. 70:255-262.

6. Collins, M. D., U. Rodrigues, C. Ash, M. Aguirre, J. A. E. Farrow, A. Martinez-Murcia, B. A. Philips, A. M. Williams, and S. Wallbanks. 1991. Phylogenetic analysis of the genus Lactobacillus and related lactic acid bacteria as determined by reverse transcriptase sequencing of $16 \mathrm{~S}$ rRNA. FEMS Microbiol. Lett. 77:5-12.

7. Dellaglio, F., V. Bottazzi, and M. Vescovo. 1975. Deoxyribonucleic acid homology among Lactobacillus species of the subgenus Streptobacterium Orla-Jensen. Int. J. Syst. Bacteriol. 25:160-172.

8. Dellaglio, F., L. M. T. Dicks, M. Du Toit, and S. Torriani. 1991. Designation of ATCC 334 in place of ATCC 393 (NCDO 161) as the neotype strain of Lactobacillus casei subsp. casei and rejection of the name Lactobacillus paracasei (Collins et al., 1989). Request for an opinion. Int. J. Syst. Bacteriol. 41:340-342.

9. Dicks, L. M. T., E. M. Du Plessis, F. Dellaglio, and E. Lauer. 1996. Reclassification of Lactobacillus casei subsp. casei ATCC 393 and Lactobacillus rhamnosus ATCC 15820 as Lactobacillus zeae nom. rev., designation of ATCC 334 as the neotype of $L$. casei subsp. casei, and rejection of the name Lactobacillus paracasei. Int. J. Syst. Bacteriol. 46:337-340.

10. Hammes, W. P., N. Weiss, and W. Holzapfel. 1992. The genera Lactobacillus and Carnobacterium, p. 1535-1594. In A. Balows, H. G. Trüper, M. Dworkin, W. Harder, and K.-H. Schleifer (ed.), The prokaryotes, 2nd ed., vol. 2. Springer-Verlag, New York, N.Y.

11. Kandler, O., and N. Weiss. 1986 Genus Lactobacillus Beijerinck 1901, p. 1209-1234. In P. H. A. Sneath, N. S. Mair, M. E. Sharpe, and J. G. Holt (ed.), Bergey's manual of systematic bacteriology, vol. 2. The Williams \& Wilkins Co., Baltimore, Md

12. Kimura, M. 1980 . A simple method for estimating evolutionary rates of base substitutions through comparative studies of nucleotide sequences. J. Mol. Evol. 16:111-120.

13. Martinez-Murcia, A. J., and M. D. Collins. 1990. A phylogenetic analysis of the genus Leuconostoc based on reverse transcriptase sequencing of $16 \mathrm{~S}$ rRNA. FEMS Microbiol. Lett. 70:73-84.

14. Perkin-Elmer Co. 1993. 373 DNA sequencing system user's manual. PerkinElmer Co., Norwalk, Conn.

15. Saitou, N., and M. Nei. 1987. The neighbor-joining method: a new method for reconstructing phylogenetic trees. Mol. Biol. Evol. 4:406-425.

16. Skerman, V. B. D., V. McGowan, and P. H. A. Sneath (ed.). 1980. Approved lists of bacterial names. Int. J. Syst. Bacteriol. 30:225-420.

17. Stackebrandt, E., and B. M. Goebel. 1994. Taxonomic note: a place for DNA-DNA reassociation and $16 \mathrm{~S}$ rRNA sequence analysis in the present species definition in bacteriology. Int. J. Syst. Bacteriol. 44:846-849.

18. Tamura, K., and M. Nei. 1993. Estimation of the numbers of nucleotide substitutions in the control region of mitochondrial DNA in humans and chimpanzees. Mol. Biol. Evol. 10:512-526.

19. Walbank, S., A. T. Martinez-Murcia, J. L. Fryer, B. A. Phillips, and M. D. Collins. 1990. 16S rRNA determination for members of genus Carnobacterium and related lactic acid bacteria and description of Vagococcus salmoninarum sp. nov. Int. J. Syst. Bacteriol. 40:224-230.

20. Wayne, L. G. 1994. Action of the Judicial Commission of the International Committee on Systematic Bacteriology on requests for opinion published between January 1985 and July 1993. Int. J. Syst. Bacteriol. 44:177-178.

21. Wittwer, C. T., and D. J. Garling. 1991. Rapid cycle DNA amplification: time and temperature optimization. BioTechniques 10:76-83.

22. Woese, C. R. 1987. Bacterial evolution. Microbiol. Rev. 51:221-271

23. Yang, D., and C. R. Woese. 1989. Phylogenetic structure of the "Leuconostoc": an interesting case of a rapidly evolving organism. Syst. Appl. Microbiol. 12:154-149. 